\title{
"The prospects of integration of the advertising market of Ukraine into the global advertising business"
}

\begin{tabular}{|c|c|}
\hline \multirow{4}{*}{ AUTHORS } & Svitlana Dombrovska (D https://orcid.org/0000-0002-8627-0057 \\
\hline & Viktoriia Shvedun (D) https://orcid.org/0000-0002-5170-4222 \\
\hline & Volodymyr Streltsov (D) https://orcid.org/0000-0002-6647-8678 \\
\hline & Kyrylo Husarov (D https://orcid.org/0000-0001-7509-8063 \\
\hline ARTICLE INFO & $\begin{array}{l}\text { Svitlana Dombrovska, Viktoriia Shvedun, Volodymyr Streltsov and Kyrylo } \\
\text { Husarov (2018). The prospects of integration of the advertising market of Ukraine } \\
\text { into the global advertising business. Problems and Perspectives in Management, } \\
\text { 16(2), 321-330. doi:10.21511/ppm.16(2).2018.29 }\end{array}$ \\
\hline DOI & http://dx.doi.org/10.21511/ppm.16(2).2018.29 \\
\hline RELEASED ON & Monday, 11 June 2018 \\
\hline RECEIVED ON & Monday, 23 April 2018 \\
\hline \multirow[t]{2}{*}{ ACCEPTED ON } & Friday, 25 May 2018 \\
\hline & $($ (c) EY-NC \\
\hline LICENSE & $\begin{array}{l}\text { This work is licensed under a Creative Commons Attribution-NonCommercial } 4.0 \\
\text { International License }\end{array}$ \\
\hline JOURNAL & "Problems and Perspectives in Management" \\
\hline ISSN PRINT & $1727-7051$ \\
\hline ISSN ONLINE & $1810-5467$ \\
\hline PUBLISHER & LLC "Consulting Publishing Company "Business Perspectives" \\
\hline FOUNDER & LLC "Consulting Publishing Company "Business Perspectives" \\
\hline
\end{tabular}

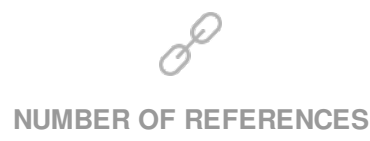

30

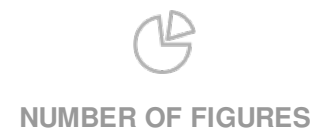

3
NUMBER OF TABLES

6

(c) The author(s) 2021. This publication is an open access article. 


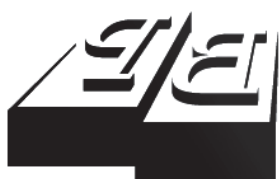

BUSINESS PERSPECTIVES

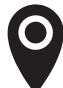

LLC "CPC "Business Perspectives" Hryhorii Skovoroda lane, 10, Sumy, 40022, Ukraine

www.businessperspectives.org

Received on: $23^{\text {rd }}$ of April, 2018 Accepted on: $25^{\text {th }}$ of May, 2018

(C) Svitlana Dombrovska, Viktoriia Shvedun, Volodymyr Streltsov, Kyrylo Husarov, 2018

Svitlana Dombrovska, Doctor of Science in Public Administration, Professor, Honored Worker of Education of Ukraine, Head of the Research, Educational and Production Center, National University of Civil Defence of Ukraine, Ukraine.

Viktoriia Shvedun, Doctor of Science in Public Administration, Senior Researcher, Head of the department on management of the Research, Educational and Production Center, National University of Civil Defence of Ukraine, Ukraine.

Volodymyr Streltsov, Doctor of Science in Public Administration, Associate Professor, Leading Researcher of the department on problems of management in the sphere of civil protection of the Research, Educational and Production Center, National University of Civil Defence of Ukraine, Kharkiv, Ukraine;

Associate Professor of the Management Department, Pomeranian University, Poland.

Kyrylo Husarov, Senior Researcher of the scientific department on problems of state security of the Research, Educational and Production Center, National University of Civil Protection of Ukraine, Ukraine.

\section{(ㄷ)(1) $(9$}

This is an Open Access article, distributed under the terms of the Creative Commons Attribution-NonCommercial 4.0 International license, which permits re-use, distribution, and reproduction, provided the materials aren't used for commercial purposes and the original work is properly cited.
Svitlana Dombrovska (Ukraine), Viktoriia Shvedun (Ukraine),

Volodymyr Streltsov (Poland), Kyrylo Husarov (Ukraine)

\section{THE PROSPECTS OF INTEGRATION OF THE ADVERTISING MARKET OF UKRAINE INTO THE GLOBAL ADVERTISING BUSINESS}

\begin{abstract}
Advertising expands and improves sales channels, accelerates money turnover, thereby increasing overall effectiveness of functioning of national economy and its integration into the world economy in general. The analysis of the current trends and future prospects of management of the advertising market of Ukraine at the world level is carried out in the article. In particular, the analysis of the current structure of the world advertising market is made. The assessment of retrospective tendencies of development of the advertising and communication market of Ukraine is carried out. The identification of perspective volumes of the advertising market of Ukraine is made. The forecast of perspective volumes of the advertising market of Ukraine within the next three years is made. In general, the given research allows to allocate problems of the modern advertising market of Ukraine and offers the ways of improvement of the state advertising policy of Ukraine.
\end{abstract}

\section{Keywords prospects, tendencies, advertising market, forecasting, state policy, Ukraine}

\section{JEL Classification M31, M37}

\section{INTRODUCTION}

Advertising activity becomes one of the spheres, which promptly develop and directly participate in creation of the new enterprises and production potential both in advertising and in other branches of economy nowadays, thus creating conditions for the capital investment. The advertising market is a part of economic system. It functions as the uniform mechanism uniting various markets and develops within the general laws of market economy. Advertising activity is the driving force of society, which is capable to form the modern systems of human values and, accordingly, the standards of human behavior. Advertising actively involves people in work, stimulates the increase of work efficiency. Advertising activity supports the competition that, in turn, promotes the growth of economic capacity of the country. Advertising expands and improves sales channels, accelerates money turnover, thereby increasing overall effectiveness of functioning of national economy and its integration into the world economy in general. At the same time, considering dynamic development of the advertising market, systematic improvement of advertising technologies, in particular, innovative types and forms of advertisement distribution, some problems are observed within management of the modern advertising market. That is why creation of the favorable environment for the formation of the civilized advertising market of Ukraine with the prospect of providing the high-quality promotional products is necessary nowadays. However, it can't be carried out without providing the profound and comprehensive analysis of the processes happening within the advertising market of Ukraine. All the aforesaid emphasizes the relevance of the research. 


\section{LITERATURE REVIEW}

Many foreign scientists and practicians offer effective approaches to solution of various problems, which arise in the process of functioning of the advertising market in present conditions. In particular, different authors pay significant attention to the essence of advertising, its types and means of its distribution and also feature of implementation of advertising activity.

In particular, some authors state that nowadays the advertising market is the developed segment of economy of many countries of the world and includes the broad system of economic, legal, social and cultural and other relations, which arise and develop between the main subjects of this market - advertisers, advertisement producers, advertising distributors and advertising consumers. There is a close economic interrelation between them, which is a basis of advertising process and functioning of the market in general. The state of the advertising market within any economy depends directly on a general economic situation in the country. Therefore, the advertising activity in the market sometimes is considered as a peculiar indicator of economic development (Bovee \& Arens, 1989).

Tareq Hashem (2017) investigates the impact of using humor advertisement on airline customers' mental image.

James B. Bexley and Karen Sherrill (2017) made a research asking the participants concerning advertisements on television, social media or the internet, billboards, traditional print media, or heard bank advertising on the radio.

It is emphasized in some works that globalization, integration and concentration are the main tendencies of development of the modern world advertising market. So, authors consider globalization as follows. The modern advertising market is a component of global economy. Therefore, the same processes as in the world economy in general take place there, on the one hand, but there are also specific phenomena within the world advertising market, on the other hand. Globalization is the general tendency for all world economy. It is the social and economic process, which, in turn, is the reason of the world turnover into the uniform market. The process of globalization is caused by a number of the following factors: activity of the multinational companies on a global scale; the increase of processes of concentration and monopolization; accelerated development of global media and global information exchange; interpenetration of various cultures and introduction of uniform cultural standards, etc. The activity of the multinational and international companies within the global market has caused the integration processes, association of its economic subjects, deepening of their interaction, development of communications between them. The economic integration has proved itself, first of all, in expansion of production and technological communications, resource sharing, association of the capitals, creating favorable conditions for economic activity, removal of mutual barriers. These processes have led to the fact that the multinational companies and brands promoted by them became leaders of the world market of consumer goods with the profits equal to budgets of many states. Nowadays the powerful global advertisers are in the lead in the markets of the majority of the countries of the world, and their expenses on advertising make a considerable part of the national advertising markets. The high level of the competition in the modern market has also caused the processes of concentration of its subjects by merger and absorption. There is an increase in economic efficiency as a result of processes of merger and absorption, because they are followed by reduction of parallel structures (administrative, research and organizational ones) (Bovee \& Thill, 1992).

Certain authors put forward the point of view that nowadays there takes place the consolidation process - absorption of small advertising agencies by large ones and certain formation of holdings. It allows advertising holdings to minimize the costs and provide a multiple complex of advertising services for the large advertisers interested in expansion of sales markets of the goods or services. The formation of the global networks by large advertising agencies has begun in the middle of the 20th century. Now several groups of companies, which have collected the most profitable part of advertising business, that, in turn, allows to them control a considerable share of 
the world advertising market, are in the leading positions of the global advertising market. These groups were formed as a result of process of merger and absorption of the agencies and companies specializing in the area of strategic communications, public relations, market researches, advances, creative and adjacent kinds of activity worldwide (Ghauri \& Kirpalani Manek, 2015).

The concept "diversification" expresses one of the tendencies of the modern advertising market connected with strengthening the activity of participants of the market, first of all, for advertising agencies and expansion of their activity. The process of diversification is caused by strengthening the competition in the market and by complication of advertising activity. "The diversification allows participants of the advertizing market to act simultaneously in several market segments and insures their actions on a case of unforeseen deterioration in an environment within one of them, helps to flexibly adapt to changes of a situation". The diversification gained a broad development during the last decades in advertizing business. It promoted the increase in flexibility of business and complex satisfaction of various demand for advertising services. The diversification of the advertising enterprises is combined with specialization and combination of different types of advertising activity that allows them to get advantages in preservation of the leading positions in the market (Czinkota, Ronkainen, \& Zvobgo, 2011).

However, the questions of determination of future volumes of the world advertising market and the researches of prospects of Ukraine within global advertizing market are still insufficiently studied.

Thus, especially relevant is studying the tendencies of development of the world advertising market in modern conditions.

Proceeding from the relevance of the research subject, the purpose of the current work is to analyze the current trends and future prospects of management of the advertising market of Ukraine in order to assess the opportunities and conditions for its integration into the global advertising business.

\section{METHOD}

The regression analysis is the theoretical basis of creation of the forecast of perspective volume of the advertising market. The given analysis is based on retrospective dynamics of change of volume of the advertising market of Ukraine and assumes determination of its perspective values on the basis of regression function (Wilson \& Keating, 1994).

The parameters of one-factorial linear regression function, which is the basis for forecasting of perspective volumes of the advertising market, are calculated with the help of the least squares method.

The one-factorial linear regression function for forecasting the perspective volumes of the advertising market is as follows:

$$
y=3649.5 \cdot x-7345124.67
$$

where $x$-time interval (year), $y$ - volume of the advertising market of Ukraine, million UAH.

The parameters of the given one-factorial linear regression function are calculated with the help of the method of least squares on the basis of the retrospective data reflecting the volume of the advertising market of Ukraine during the period 2011-2017 (Table 2). In particular, the parameter 3649.5 of the received dependence means the speed of the annual change of volumes of the advertising market of Ukraine. The second parameter of the given model - 7,345,124.67 - is a constant and actually means the deviation caused by influence of unaccounted factors on the volume of the advertising market of Ukraine.

The multiple coefficient of determination is the criterion of adequacy and reliability of the received model.

\section{RESULTS}

\subsection{The research of the general tendencies of development of the global advertising market}

Nowadays $41.6 \%$ of the world advertising market is occupied by the USA, Japan makes $10 \%$, and the combined share of Great Britain, Germany and 


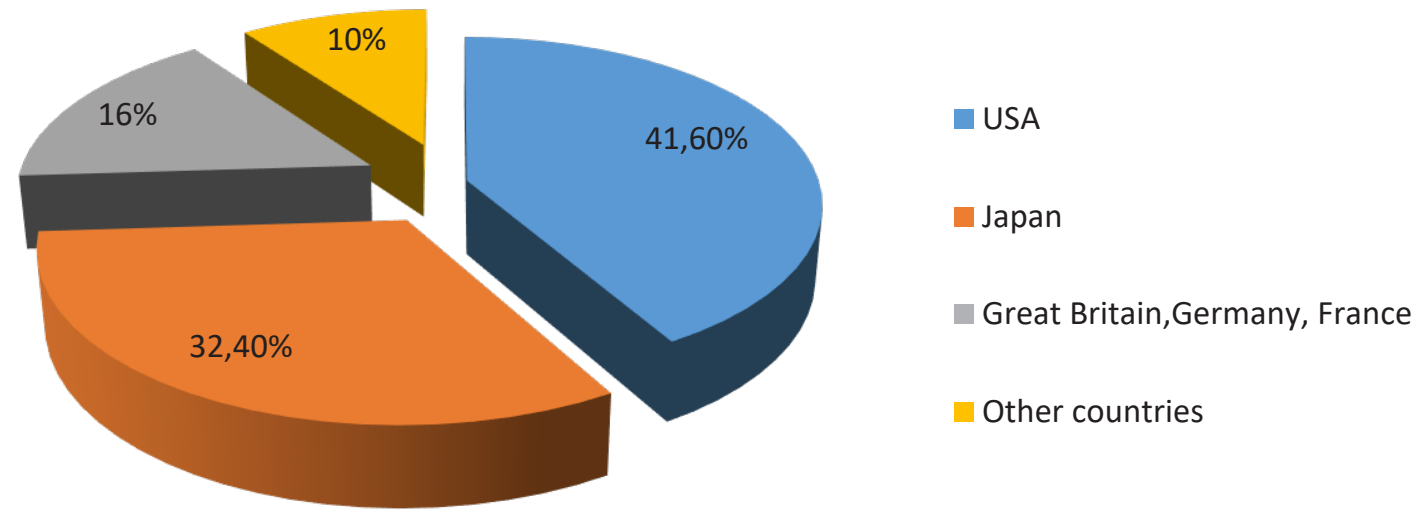

Figure 1. Structure of the world advertising market in 2017

France is about $16 \%$ (Figure 1). At the same time, the volumes of national advertising markets of the leading countries grow very slowly.

The total volume of the world advertising market in 2013 was near USD 503 billion. Thus, it is possible to see from Table 1 that the $1^{\text {st }}$ place in the world advertising market in 2013 was taken by the USA with the volume of advertising expenses near USD 166.9 billion or $33.2 \%$ of the total amount of the global advertising market. As for Japan, its advertising market share was about $10.4 \%$ in 2013 (the advertising expenses volume was near USD 52.4 billion).

In 2013, China took the $3^{\text {rd }}$ place of the world advertising market with the volume of advertising expenses near USD 40.95 billion or advertising market share of $8.1 \%$. Shares of the advertising market of Germany and Great Britain reached $4.6 \%$ and $4.0 \%$, respectively.
As for the shares of advertising market of Brazil, Australia, France, Canada and South Korea, they also differ insignificantly and reached $3.2 \%, 2.6 \%$, $2.4 \%, 2.3 \%$ and $2.1 \%$, respectively, in 2013 .

The total volume of the world advertising market in 2016 was near USD 505 billion. As it is indicated in Table 1, the $1^{\text {st }}$ place in the world advertising market in 2016 was taken by the USA again with the volume of advertising expenses near USD 190.27 billion or $37.7 \%$ of the total amount of the global advertising market. Thus, the volume of the USA advertising market increased in 2016 by USD 23.37 billion in comparison with 2013.

As for Japan, its advertising market share was about $11.1 \%$ in 2016 (the advertising expenses volume was near 56.25 billion USD). So, the volume of advertizing market of Japan increased by 3.85 billion USD in 2016 in comparison with 2013.

Table 1. The comparative structure of the world advertising market in 2013 and 2016

Source: Own calculation on the basis of Root (1994), "Volume of advertising" (2017).

\begin{tabular}{|c|c|c|c|c|}
\hline Country & $\begin{array}{c}\text { Advertising expenses in } \\
2013 \text {, billion USD }\end{array}$ & $\begin{array}{c}\text { Advertising expenses in 2016, } \\
\text { billion USD }\end{array}$ & $\begin{array}{c}\text { Absolute deviation, } \\
\text { billion USD }\end{array}$ & $\begin{array}{c}\text { Relative } \\
\text { deviation, \% }\end{array}$ \\
\hline USA & 166.9 & 190.27 & 23.37 & 14.00 \\
\hline Japan & 52.4 & 56.25 & 3.85 & 7.34 \\
\hline China & 40.95 & 55.36 & 14.41 & 35.19 \\
\hline Germany & 23.18 & 24.15 & 0.97 & 4.18 \\
\hline Great Britain & 20.35 & 23.96 & 3.61 & 17.73 \\
\hline Brazil & 15.86 & 18.88 & 3.02 & 19.04 \\
\hline Australia & 13.07 & 14.26 & 1.19 & 9.10 \\
\hline South Korea & 10.61 & 13.76 & 3.15 & 29.69 \\
\hline
\end{tabular}




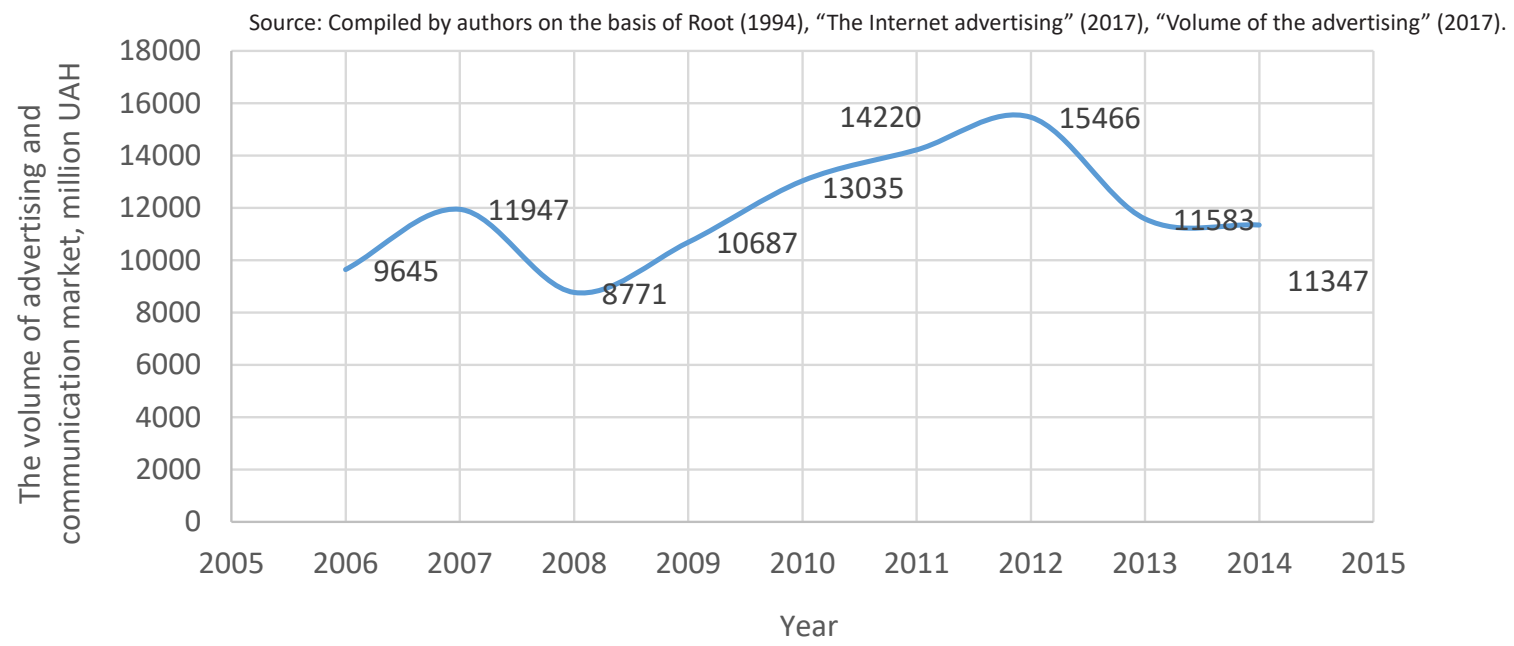

Figure 2. Dynamics of change of volume of the advertising and communication market of Ukraine during the period 2007-2015

China again took the $3^{\text {rd }}$ place of the world advertising market with the volume of advertizing expenses near USD 55.36 billion or advertising market share of $11.0 \%$. So, the volume of advertising market of China increased by USD 14.41 billion in 2016 in comparison with 2013.

Shares of the advertizing market of Germany and Great Britain reached $4.8 \%$ and $4.7 \%$ respectively.

As for the shares of advertising market of Australia and South Korea, they also differ insignificantly and reached $2.8 \%, 2.7 \%, 2.6 \%$ and $2.6 \%$, respectively, in 2016.

Actually, the distribution of the world advertising market in 2016 looked identically to 2013 with the only difference that Russia and Indonesia took to the top ten countries of the global advertising market instead of France and Canada in 2016.

At the same time, it should be noted that the highest growth rate of the advertising market is noted in China (35.19\%). Brazil takes the $2^{\text {nd }}$ place $(19.04 \%)$. And Great Britain is on the $3^{\text {rd }}$ place $(17.73 \%)$.

But, as it is possible to see from the performed analysis, the USA and Japan remain leaders of the world advertizing market already at least within the last 4 years.

As for the further forecast of development of the world advertising market, it is possible to sign that the largest markets (the USA, China, Japan, Great
Britain and Germany) will make $57 \%$ of the advertising market between 2017 and 2020.

At the same time, it is expected that the volume of the world advertising market will be USD 544 billion in 2018. Distribution of the world advertising market by advertising means is expected in the following format in 2018 .

Thus, it is expected that the biggest share of the world advertising market will belong to TV advertising (37.3\%) in 2018. The desktop internet will take the second place $-18.7 \%$. The shares of the advertising market relating to the mobile internet and newspapers will be practically identical and will approximately make $12.7 \%$ and $12.0 \%$, respectively. The shares of magazines, online video and radio will make $5.9 \%$, $6.6 \%$ and $6.3 \%$, respectively. The smallest share of the advertising market will be taken by movie theaters $-0.5 \%$.

However, it should be mentioned that Ukraine, for example, isn't the leading country concerning advertising development in the world.

\subsection{The analysis of tendencies of management of the advertising market of Ukraine}

In general, the dynamics of change of total amount of the advertising and communication market of Ukraine during the period 2007-2015 is shown in Figure 2. 
Figure 2 indicates that dynamics of the advertising and communication market of Ukraine displays rapid growth throughout the beginning of the specified period, except for 2009, which was the following after 2008 crisis when the total amount of the advertising and communication market of Ukraine showed the rate of falling at the level of $24 \%$.

The following period 2010-2013 was designated by fluctuation of volumes of the advertising and communication market of Ukraine. Concerning the period 2014-2015, volumes of the domestic advertising and communication market of Ukraine decreased against background of the crisis situation in the country. So, in 2015, the volume of the advertising and communication market of Ukraine decreased in comparison with 2013 by UAH 3883 million or for $25 \%$.

Concerning the change in comparison with the previous 2014, its volume decreased by UAH 236 million or for $2 \%$. Comparing the value of volumes of the advertising market of Ukraine in 2015 and in 2008 in general, it is expedient to note that 2015 shows the value, which is even lower than value of 2008 for UAH 600 million, or for 5\%. Such situation can be caused by increase in number of violations of the advertising legislation against the background of lack of constant system of state regulation of advertising activity in Ukraine.

Thus, on the basis of the conducted researches, it is possible to make a conclusion that transformation of advertising of Ukraine into qualitatively new form of production relations reflects a positive tendency of further improvement of mechanisms of state regulation in the sphere of advertising activity in Ukraine. But advertising in Ukraine isn't developed at the present stage so that Ukraine could be included into world top ten countries of the advertising industry.

That is why forecasting of perspective tendencies of development of the Ukrainian advertising market for the purpose of identification of the specified opportunities is expedient.

It is possible to obtain statistical data for forecasting of further tendencies of development of the advertising market of Ukraine taking away the sum of the agency commissions and the fees and taking into account only the total amount of the advertising and communication market of Ukraine during the period 2011-2017 (Table 2)

It is offered to perform the forecasting of perspective volume of the advertising market of Ukraine by means of regression analysis.

It is necessary to create the diagram of dependence of volumes of the advertising market of Ukraine on the given intervals of time (years) for determination of expedient regression function, which needs to be used for implementation of forecasting of perspective volumes of the advertising market of Ukraine during the next three years (Figure 3).

Source: Compiled by authors on the basis of Root (1994), "The Internet advertising" (2017), "Volume of the advertising" (2017).

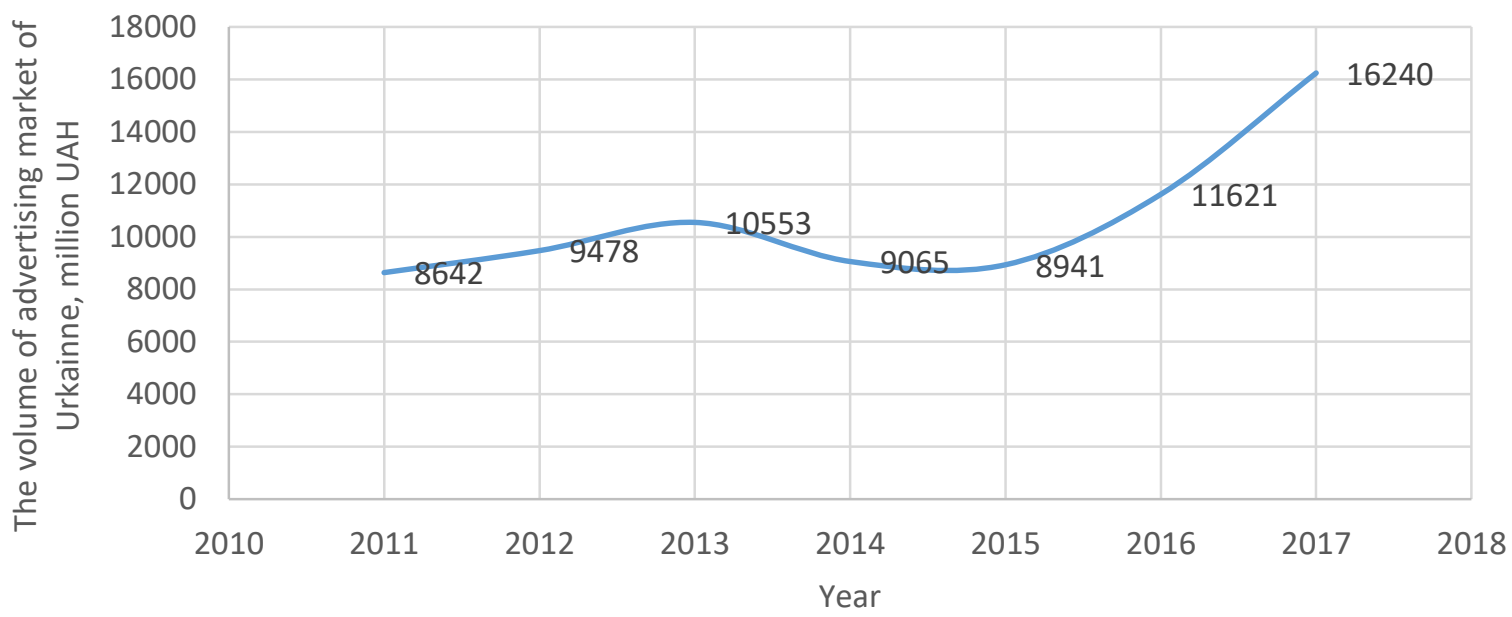

Figure 3. The tendencies of change of volume of the advertising market of Ukraine during the period 2011-2017 
Table 2. The dynamics of the advertising market of Ukraine during the period 2011-2015

Source: Compiled by authors on the basis of Root (1994), "The Internet advertising" (2017), "Volume of the advertising" (2017)

\begin{tabular}{c|c}
\hline Year & $\begin{array}{c}\text { Volume of the advertising market of } \\
\text { Ukraine, million UAH }\end{array}$ \\
\hline 2011 & 8,642 \\
\hline 2012 & 9,478 \\
\hline 2013 & 10,553 \\
\hline 2014 & 9,065 \\
\hline 2015 & 8,941 \\
\hline 2016 & 11,621 \\
\hline 2017 & 16,240 \\
\hline
\end{tabular}

Figure 3 allows to observe the linear dependence between volumes of the advertising market of Ukraine and the time interval.

Thus, Figure 3 illustrates the non-linear change of volume of the advertising market of Ukraine during the period 2011-2017.

\subsection{The forecasting of the perspectives of development of the advertising market of Ukraine}

The forecast of perspective development of the advertising market of Ukraine, received by means of the regression analysis, is shown in Table 3.

Table 3. The expected dynamics of change of volume of the advertizing market of Ukraine during the period $2018-2020$

Source: Own calculations.

\begin{tabular}{c|c}
\hline Year & $\begin{array}{c}\text { Expected volume of the advertising } \\
\text { market of Ukraine, million UAH }\end{array}$ \\
\hline 2018 & 17,518 \\
\hline 2019 & 19,939 \\
\hline 2020 & 22,359 \\
\hline
\end{tabular}

Comparing the expected values of the advertising market of Ukraine for the next three years received by means of use of the regression function with the forecasts of experts of the all-Ukrainian advertising coalition, it is possible to see that these values significantly differ (Table 4).

So, concerning forecasts of the all-Ukrainian advertizing coalition, the volume of the advertising market of Ukraine will reach UAH 20,460 million in 2018.

Concerning the results of forecasting by means of the regression function, its value will approximately be UAH 17,518 million in 2018 , i.e., considering the existing tendencies, the volume of the advertising market of Ukraine will increase, but the growth rate will be much lower.

As it is possible to see from Table 4, the expected growth rate of volume of the advertising market of Ukraine according to results of the forecast received by use of the regression function is nearly 3 times less than its expected growth rate received according to assessment of experts of the all-Ukrainian advertising coalition in 2018.

At the same time, considering the forecasts of experts of the International Monetary Fund concerning growth rates of the Ukrainian economy in 2018, it should be noted that it is expected approximately at the level of $3.2 \%$. Accordingly, the growth rate of the advertising market of Ukraine at the level of $26 \%$ in 2018 cannot be considered as a real value, considering that the volume of the advertising market of Ukraine decreased during the period 2013-2015 (in particular, it decreased for $14 \%$ in 2014 in comparison with the previous 2013 and also decreased for $1.4 \%$ in 2015 in comparison with the previous 2014).

Table 4. The comparative characteristic of forecasts of volume of the advertising market of Ukraine for 2018

Source: Own calculation on the basis of Ricks (2006), "The Internet advertising" (2017).

\begin{tabular}{|c|c|c|c|c|c|}
\hline Indicator & $\begin{array}{l}\text { The results of } \\
2017 \text {, million } \\
\text { UAH }\end{array}$ & $\begin{array}{c}\text { The forecast for } 2018, \\
\text { million UAH (all- } \\
\text { Ukrainian advertising } \\
\text { coalition) }\end{array}$ & $\begin{array}{l}\text { Growth } \\
\text { rate, \% }\end{array}$ & $\begin{array}{l}\text { The forecast for } \\
\text { 2018, million } \\
\text { UAH } \\
\text { (regression } \\
\text { function) }\end{array}$ & Growth rate, $\%$ \\
\hline $\begin{array}{l}\text { The advertising market of } \\
\text { Ukraine }\end{array}$ & 16,240 & 20,460 & 26 & 17,518 & 7.9 \\
\hline
\end{tabular}


Thus, the general dynamics of change of volume of the advertising market of Ukraine for the period 2011-2020 is shown in Table 5.

Table 5 show that steady increase in volume of the advertising market of Ukraine will be observed during the period 2018-2020. At the same time, its growth rate will eventually be gradually slowed down.

Table 5. The dynamics of change of volume of the advertising market of Ukraine during the period 2011-2018, million UAH

Source: Compiled by authors on the basis of Root (1994), "The Internet advertising" (2017), "Volume of the advertising" (2017).

\begin{tabular}{c|c|c}
\hline Year & $\begin{array}{c}\text { Volume of the advertising } \\
\text { market of Ukraine, million } \\
\text { UAH }\end{array}$ & $\begin{array}{c}\text { Growth } \\
\text { rate, \% }\end{array}$ \\
\hline 2011 & 8,642 & - \\
\hline 2012 & 9,478 & 9.7 \\
\hline 2013 & 10,553 & 11.3 \\
\hline 2014 & 9,065 & -14.1 \\
\hline 2015 & 8,941 & -1.4 \\
\hline 2016 & $\mathbf{1 1 , 6 2 1}$ & $\mathbf{3 0 . 0}$ \\
\hline 2017 & $\mathbf{1 6 , 2 4 0}$ & $\mathbf{3 9 . 7}$ \\
\hline 2018 & 19,566 & 20.5 \\
\hdashline 2019 & 23,216 & 18.7 \\
\hline 2020 & 26,865 & 15.7 \\
\hline
\end{tabular}

Carrying out recalculation of perspective volumes of the advertising market of Ukraine in USD, it is possible to receive their following dynamics for the next three years (Table 6).

Table 6. The perspective dynamics of change of volume of the advertizing market of Ukraine during the period 2018-2020, billion USD

Source: Own calculation.

\begin{tabular}{c|c}
\hline Year & $\begin{array}{c}\text { Volume of the advertising market } \\
\text { of Ukraine, billion USD }\end{array}$ \\
\hline 2018 & 0.72 \\
\hline 2019 & 0.86 \\
\hline 2020 & 0.99 \\
\hline
\end{tabular}

Considering that according to the experts' assessments, the world advertising market will make USD 559 billion in 2018, it is possible to calculate the corresponding share of the advertising market of Ukraine.

Thus, the share of the advertising market of Ukraine at the world level will make $0.2 \%$ in 2018 , which is a very negative indicator.

One of the possible reasons of such situation is the imperfection of the organizational and legal mechanism of state regulation of advertising activity in Ukraine.

So, in the context of the economic direction of improvement of state policy in the sphere of advertising activity of Ukraine, it is supposed to make following:

- reduction of tax burden of the organizations, which are engaged in development and distribution of advertising;

- organization of competitions and stimulation by means of grants of the most successful innovative advertising projects;

- full support of research and design works and also stimulation of demand for innovative projects that, in turn, will have a positive impact on processes of development of both innovative and classical advertising.

\section{DISCUSSION}

The one-factorial function of linear regression is a basis for creation of model of forecasting of perspective volumes of the advertising market of Ukraine. The multiple coefficient of determination, which is the criterion of adequacy of the received model, is the closest to 1 that confirms the high degree of reliability of expected values. Nevertheless, the model partially considers influence of different factors on development of the advertising market of Ukraine. Therefore, it is necessary to consider the greatest possible quantity of these factors in perspective researches. 


\section{CONCLUSION}

Thus, as a result of carrying out the given research, the following conclusions wereobtained. The volume of the modern world advertising market promptly increases during the last years. The highest growth rate of the advertising market is noted in China (35.19\%). Brazil takes the $2^{\text {nd }}$ place (19.04\%). And Great Britain is on the $3^{\text {rd }}$ place (17.73\%). At the same time, the USA, Japan and China remain leaders of the world advertizing market. The advertising market of Ukraine still remains too small at the world level during the last years.

The modern advertising market of Ukraine looks unstable considering that advertising expenses for the last 7 years fluctuate. The possible reasons could cause the given situation: low quality of the advertising product in Ukraine; imperfection of the advertising legislation; insufficient level of the competition on commodity market and services. The forecasts of the all-Ukrainian advertizing coalition confirm perspective increase of the volume of the advertising market of Ukraine by $26 \%$. However, the economic and mathematical model offered in this research disproves results of the forecast of the all-Ukrainian advertising coalition and shows that the growth rate of the advertising market of Ukraine will be lower within the next 3 years $-7.9 \%$. There is a tendency for increasing volumes of the advertising market of Ukraine, but its growth rate demonstrated the decreasing tendency. Ukraine has a possibility of entry into the world advertizing market in the conditions of improvement of its state advertising policy concerning advertising legislation and decreasing volumes of its violations. First of all, it is necessary to make the adaptation of the Law of Ukraine "About advertising" according to standards of the international regulation of the advertising activity.

\section{REFERENCES}

1. Amato, L., \& Wilder, R. (2004). Global Competition and Global Markets: Some Empirical Results. International Business Review, 13(3), 401-416.

2. Bird, A., \& Stevens, M. (2003). Toward an emerging global culture and the effects of globalisation on obsolescing national cultures. Journal of International Management, 6 , 395-407.

3. Bovee, Courtland L., \& Thill, John V. (1992). Marketing (811 p.). New York: McGraw - Hill.

4. Bovee, Courtland, L., \& Arens, William F. (1989). Contemporary advertising (662 p.). Homewood: Irwin.

5. Brown, R. G. (1963). Smoothing, Forecasting and Prediction (468 p.). Cliff, New Jersey: Prentice-Hall.

6. Burns, Alvin C., \& Bush, Ronald F. (2003). Marketing Research (642 p.). New Jersey: Prentice Hall.

7. Cateora, Philip R., \& Graham, John L. (2011). International Marketing (622 p.). Irwin: McGraw-Hill.
8. Clark, T., \& Mathur, L. L. (2003). Global Myopia: Globalisation Theory in International Business. Journal of International Management, 9, 361-372.

9. Czinkota, M., Ronkainen, I., \& Zvobgo, G. (2011). International marketing (752 p.). Hampshire: Cengage Learning EMEA.

10. Ghauri, P. N., \& Cateora, P. R. (2010). International marketing (332 p.). Irwin: McGraw-Hill Higher Education.

11. Ghauri, P., \& Kirpalani Manek, V. H. (2015). International Entrepreneurship Strategy: Improving SME Performance Globally (432 p.). London: Edward Elgar Publishing.

12. Ghemawat, Punkaj (2003). Semiglobalisation and International Business Strategy. Journal of International business Studies, 34(1), 139-152.

13. Granger, C. W. J. (1990). Modeling Economic Series (419 p.). Oxford: Oxford University Press.
14. Harris, G. (1994). International Advertising Standardization: What do the Multinationals Actually Standardize. Journal of International Marketing, 2, 13-30.

15. Hollensen, S. (1998). Global Marketing - Market-Respective Approach. Hertfordshire. New Jersey: Prentice Hall.

16. James, B. Bexley, \& Karen, Sherrill (2017). Where to put your money to get their money: a bank advertising awareness study. Banks and Bank Systems, 12(1-1), 152-159.

17. Kanso, A. M., \& Nelson, R. A. (2007). Multinational Corporations and the Challenge of Global Advertising: what do US Headquarters Consider Important in Making Media-selection Decisions. International Marketing Review, 24, 563-590.

18. Ko, E. (2007). Cross-national Market Segmentation in the Fashion Industry: a Study of European, Korean, and US Consumers. International Marketing Review, 24, 629-651. 
19. Little John D. C. (1996). A Model of Adaptive Control of Promotional Spending. Operations Research, 163, 175-197.

20. Nelson, P. (1974). Advertising as Information. Journal of Political Economy, 82, 729-754.

21. Ricks, David A. (2006). Blunders in International Business (192 p.). London: Wiley-Blackwell.

22. Romin, A. V., Dombrovska, S. M., \& Shvedun, V. O. (2018). Aspects of development and implementation of financial strategy of higher educational institution. Financial and credit activity: problems of theory and practice, 1(24), 461-468.

23. Root, R. F. (1994). Entry Strategies for International Markets (324 p.). San Francisco, California: Jossey-Bass, Inc. Publishers.
24. Streltsov, V., \& Moskalenko, O. (2015). The European Parliament in the EU-Ukraine relations from independence to Orange revolution. Eastern Journal of European Studies, 6(2), 111-129.

25. Tareq Hashem (2017). Impact of using humor advertisement on airline customers' mental image. Innovative Marketing, 13(3), 25-32. https://doi.org/10.21511/ im.13(3).2017.03

26. The Internet advertising share in global expenses will reach $40 \%$ in 2018 (2017). Retrieved from http://mmr.ua/tags/ZenithOptimedia\#1556036473.1518525932/ (accessed on February 13, 2018).

27. The world advertizing market was stabilized (2013). Retrieved from http://www.advertology.ru/ article117805.htm/ (accessed on February 13, 2018).
28. Volume of the advertising and communication market of Ukraine 2016 and forecast of volume of the market of 2017 (2017). Retrieved from http://sostav.ua/ publication/obem-reklamnokommunikatsionnogo-rynkaukrainy-2016-i-prognoz-obemov-rynka-2017-73391.html/ (accessed on 13 February 2018).

29. Wilson, J. H., \& Keating, B. (1994). Business Forecasting (476 p.). Irwin: McGraw-Hill Companies.

30. Zenith Optimedia: the global advertising market will grow by $6.1 \%$ in 2016 (2015). Retrieved from http://mmr. ua/show/zenithoptimediaglobalnyj-reklamnyj-rynokvyrastit-na-61-v-2016-godu /39159\#1556036473.1518525932/ (accessed on February 13, 2018). 